\title{
Abundance and spatial-temporal distribution of Macrobrachium surinamicum Holthuis, 1948 (Palaemonidae) in the Amazon estuary, north of Brazil
}

\author{
D. V. Cavalcante ${ }^{a}$, B. S. Bentes ${ }^{b}$ and J. M. Martinelli-Lemos ${ }^{a *}$ \\ ${ }^{a}$ Grupo de Pesquisa em Ecologia de Crustáceos da Amazônia, Laboratório de Biologia Pesqueira e Manejo de Recursos \\ Aquáticos, Universidade Federal do Pará - UFPA, Av. Perimetral, 2651, CEP 66077-530, Belém, PA, Brazil \\ 'Instituto de Estudos Costeiros - IECOS, Universidade Federal do Pará - UFPA, Campus de Bragança, \\ Alameda Leandro Ribeiro, s/n, CEP 68600-000, Bragança, PA, Brazil \\ *e-mail: jussara@ufpa.br
}

Received: January 8, 2016 - Accepted: March 17, 2016 - Distributed: August 31, 2017

(With 5 figures)

\begin{abstract}
Macrobrachium surinamicum is a small shrimp that inhabits rivers of low salinity. It is mainly caught as bycatch in Amazon shrimp Macrobrachium amazonicum fisheries, which is widely exploited by artisanal fisheries for food and economic needs of the riverside population. This study aimed to characterize the spatial and temporal distribution of the freshwater shrimp M. surinamicum in the Guajará Bay and on Mosqueiro Island, correlating the abundance of this species with abiotic factors (temperature and salinity). Samples were taken from May 2006 to April 2007 in six locations: Mosqueiro Island (Furo das Marinhas and Porto do Pelé); Icoaraci district; Arapiranga Island, edge of the city of Belém; and Combu Island, using traps named 'matapis'. A total of 361 shrimps were caught. The abundance was higher in December and lower in July 2006. The biggest catch occurred on Arapiranga Island and the lowest on Mosqueiro Island. The abundance differed significantly in December 2006 and no variable studied had significant influence on M. surinamicum abundance. In Guajará Bay, particularly the more sheltered places, as Arapiranga and Combu islands, favor the development of M. surinamicum, indicating that this species has preference for less disturbed areas.
\end{abstract}

Keywords: Crustacea, Decapoda, ecology, freshwater shrimp.

\section{Abundância e distribuição espaço-temporal de Macrobrachium surinamicum Holthuis, 1948 (Palaemonidae) em um estuário Amazônico, norte do Brasil}

\begin{abstract}
Resumo
Macrobrachium surinamicum é um camarão de pequeno porte que habita a foz de rios e águas de baixa salinidade. Sua captura na Amazônia ocorre principalmente como fauna associada à pesca do camarão-da-Amazônia Macrobrachium amazonicum que é largamente explorado pela pesca artesanal atendendo as necessidades alimentícias e econômicas da comunidade ribeirinha. $\mathrm{O}$ presente estudo teve como objetivo caracterizar a distribuição espaço-temporal do camarão dulcícola M. surinamicum na Baía do Guajará e Ilha de Mosqueiro, correlacionando a abundância desta espécie com fatores abióticos (temperatura e salinidade). Os exemplares foram capturados no período de maio/06 a abril/07 em seis locais: Ilha de Mosqueiro (Furo das Marinhas e Porto do Pelé), Distrito de Icoaraci, Ilha do Arapiranga, orla de Belém e Ilha do Combu com armadilhas (matapis). Um total de 361 camarões foi capturado, sendo a maior abundância em dezembro e a menor em julho de 2006. A maior captura foi na Ilha de Arapiranga e a menor na Ilha de Mosqueiro. A abundância diferiu significativamente em dezembro/06 e nenhuma variável estudada teve influência significativa na abundância de $M$. surinamicum. A Baía do Guajará, especialmente os locais mais abrigados como a Ilha de Arapiranga e do Combu, propiciam o desenvolvimento de M. surinamicum, o que indica que esta espécie tenha preferência para áreas menos antropizadas.
\end{abstract}

Palavras-chave: Crustacea, Decapoda, ecologia, camarão dulcícola. 


\section{Introduction}

Shrimp Macrobrachium (Palaemonidae) Bate, 1968 is characterized by a wide worldwide distribution in fresh and estuarine waters and occur widely in tropical and subtropical areas of the world (Odinetz-Collart and Moreira, 1993; Short, 2004).

Numerous species that belong to this genus are of a large commercial interest, both for aquaculture and exploitation of natural stocks (Odinetz-Collart and Moreira, 1993). In Brazil, native species of freshwater shrimp are commonly caught by artisanal fishing, and the non-native shrimp Macrobrachium rosenbergii is grown in more often. The continuity of the investigations with native species is required in relation to geographic distribution, life cycle, reproduction, growth, etc., in order to develop appropriate aquaculture technology to the Brazilian reality and, in the near future, allow producers other options for cultivation (Silva et al., 2004), reducing the overexploitation of natural and impacts of invasive species escape in inland and coastal waters stocks.

Macrobrachium surinamicum Holthuis, 1948 is a small shrimp that inhabit rivers mouths and low-salinity waters (Cervigón et al., 1992). Catches of these shrimps take place in the Amazon region as bycatch in Amazon shrimp Macrobrachium amazonicum Bate, 1968 fisheries (Espírito-Santo et al., 2005; Cavalcante, 2008), which is widely exploited by artisanal fisheries in order to meet food and economic needs of the riverside community (Bentes et al., 2011). Its distribution occurs in the Atlantic Ocean from Venezuela, Colombia, Suriname, and Guyana up to Brazil (States of Amapá and Pará) (Melo, 2003). The records of this species in Brazil confirm the occurrence of the Lower Amazon and the river basins Tocatins (Pileggi et al., 2013).

Tropical freshwater shrimps live in waters at temperatures ranging from 28 to $32^{\circ} \mathrm{C}$, although they can tolerate minimum temperature of $15^{\circ} \mathrm{C}$ and maximum of $35^{\circ} \mathrm{C}$ in the case of extreme conditions (Valenti, 1996). All species that occur along with $M$. amazonicum have an area of occurrence fully included in the region limited by $25^{\circ} \mathrm{C}$ isotherm for the average air temperature of the hottest month (Coelho and Ramos-Porto, 1985). All of them occur in low-altitude locations; however, M. amazonicum, M. jelskii and possibly some other species exceed the limit of 400 meters above sea level. The occurrence area of M. surinamicum corresponds only to the coastal basins of northern Brazil and the Guianas, Venezuela and Colombia (Coelho and Ramos-Porto, 1985).

Studies on the distribution of species in natural environments are of great importance, because they contribute significantly to the understanding of their biology, management and conservation of the species. In this work, we characterized the spatio-temporal distribution of freshwater shrimp M. surinamicum density along the Guajará Bay and surroundings and the possible correlation between the abundance of these organisms and abiotic factors (temperature and salinity).

\section{Material and Methods}

Guajará Bay is part of the Amazon estuary, located to the west of the city of Belém (Figure 1). It is narrow and elongated, situated between the mainland and three fluvial islands (Onça, Arapiranga, and Cotijuba), in connection with Marajó Bay, and further north includes Mosqueiro Island and Outeiro district (Moreira, 1966). It is located in a highly dynamic environment, with strong tidal currents and waves generated by the wind, with enough power to provide the mixture of waters and re-suspension of bottom sediments. In the low rainfall season, the waters are brackish due to the penetration of seawater (Ribeiro, 2004). Due to its proximity to the Atlantic Ocean, it is subject to the influence of oceanic macrotides.

The climate of the region is hot and humid with average temperatures between 23 and $32{ }^{\circ} \mathrm{C}$, which suffer daily slight variations (two to three degrees). The average relative air humidity is $85 \%$, with peaks of up to $100 \%$ between December and May (rainy season). The average annual rainfall ranges from 2500 to $3000 \mathrm{~mm}$ (Ramos, 2004).

The expeditions for the collection of shrimps M. surinamicum took place monthly from May 2006 to April 2007, in six locations: Mosqueiro Island (Furo das Marinhas and Porto do Pelé); Icoaraci district; Arapiranga Island; edge of the city of Belém; and Combu Island, between the following latitudes and longitudes: $1^{\circ} 10^{\prime} \mathrm{S}$ and $48^{\circ} 19^{\prime} \mathrm{W}$; $1^{\circ} 10^{\prime} \mathrm{S}$ and $48^{\circ} 33^{\prime} \mathrm{W}$; $1^{\circ} 30^{\prime} \mathrm{S}$ and $48^{\circ} 19^{\prime} \mathrm{W}$; and $1^{\circ} 30^{\prime} \mathrm{S}$ and $48^{\circ} 33^{\prime} \mathrm{W}$. Such sampling was performed by using traps called 'matapis' (fishing gear made of natural fibers and recycled PET bottles), commonly used by the riverside population to catch shrimps in the area studied. Pairs of traps of two sizes were randomly placed in each location. The size specifications of the dimensions of each one of the traps are described in Bentes et al. (2011). A total of 144 samples were collected ( 6 sites - 2 traps - 12 months).

Abundance was expressed by the number of individuals caught by matapi at each site and month of collection (Catch per unit of effort - CPUE). For the standardized effort per month $\left(\mathrm{CPUE}_{\text {month }}\right)$, we considered the sum of the number of shrimps collected in all matapis of a particular month. The effort by collection site $\left(\mathrm{CPUE}_{\text {site }}\right)$ corresponded to the sum of the number of individuals collected in all matapis at a particular site.

In order to determine differences in the medians of abundance, cephalothorax length (CL), biomass ( $\mathrm{g}$ ) between the sexes, as well as the variation of abiotic factors with respect to months, periods of the year and sites, we used the non-parametric Kruskal-Wallis test, followed by Duncan's post-hoc test, since the assumptions of normality and homogeneity of variances were not met, even after undergoing transformations.

Abundance of shrimps was correlated to abiotic factors (temperature and salinity) using Spearman rank correlation. Data analyses were performed by using BioEstat ${ }^{\circledR} 5.0$ (Ayres et al., 2007) and Statistica ${ }^{\circledR} 7.0$ (Statsoft, 2004), adopting a significance level of $95 \%$. 


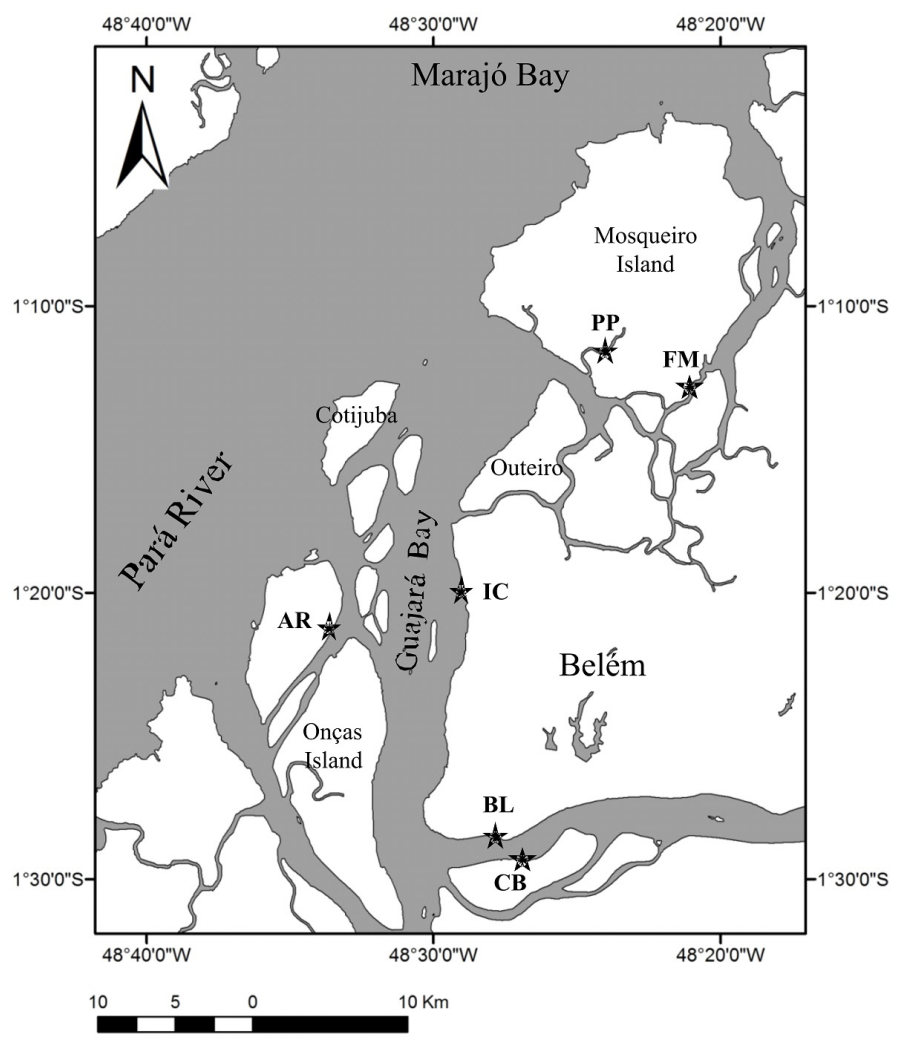

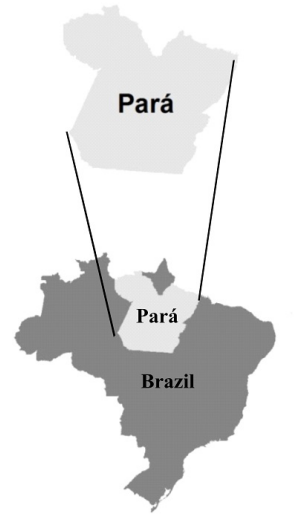

Legends

Pará

Brazil

Drainage

Sampling sites

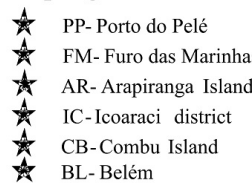

Figure 1. Macrobrachium surinamicum sampling sites in Guajará Bay and Mosqueiro Island, north of Brazil.

\section{Results}

Rainfall ranged from $33.7 \mathrm{~mm}$ in October 2006 (less rainy season) to a maximum of $440.3 \mathrm{~mm}$ in May 2007 (rainy season) (Figure 2).

The minimum salinity was zero at all locations and the maximum was eight in Furo das Marinhas (Mosqueiro Island). The lowest average occurred in Belém ( $1.45 \pm 2.27$ standard deviation) and the highest in Furo das Marinhas $(3.16 \pm 3.37)$ (Table 1$)$. Regarding salinity values, no significant difference was observed with respect to the sites $(H=1.43 ; p>0.05)$. However, there was significant difference of this variable with respect to the months $(\mathrm{H}=64.37 ; \mathrm{p}<0.05)$ and also when grouped into periods $(H=47.95 ; p<0.05)$. Salinity differed significantly from the others from August to November, and salinity medians of the rainy season showed significant differences compared to the less rainy season (Figure 3).

Water temperature ranged from $23.5^{\circ} \mathrm{C}$ on Combu Island to $29.0^{\circ} \mathrm{C}$ in Belém and $29.0^{\circ} \mathrm{C}$ in Furo das Marinhas, showing amplitude variation of $5.5^{\circ} \mathrm{C}$, with the lowest average $\left(26.39 \pm 0.76^{\circ} \mathrm{C}\right)$ on Arapiranga Island and the highest $\left(27.84 \pm 0.44^{\circ} \mathrm{C}\right)$ in Icoaraci (Table 1). Temperature differed significantly with respect to the sites $(\mathrm{H}=25.39$; $\mathrm{p}<0.05$ ) and Icoaraci differed significantly compared to the others. However, there was no significant difference of this factor with respect to months $(\mathrm{H}=10.26 ; \mathrm{p}>0.05)$, nor

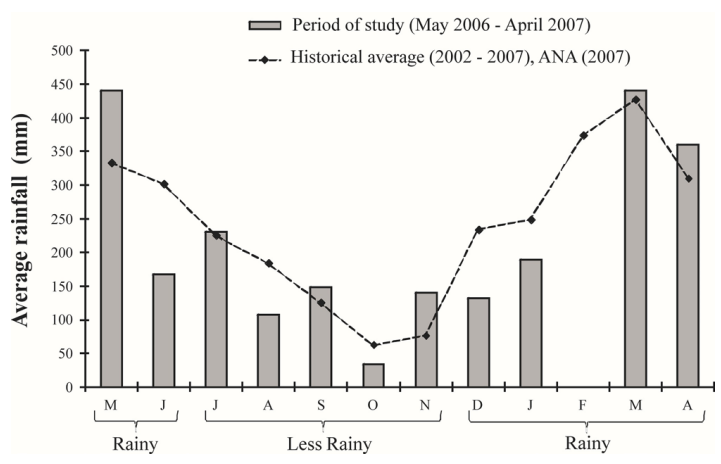

Figure 2. Total monthly rainfall (2006-2007) and monthly rainfall average during the five-year period (2002-2006) in Guajará Bay, Belém, Pará (2001-2006). Data for February 2007 were not available due to a technical problem.

with respect to the periods of the year $(\mathrm{H}=1.18 ; \mathrm{p}>0.05)$ (Figure 3).

A total of 361 shrimps were caught during the collection period. The largest abundance was recorded in December $2006(\mathrm{n}=72)$ and the lowest in July $2006(\mathrm{n}=4)$. Shrimp collection was higher on Arapiranga Island $(n=124)$ and lower on Mosqueiro Island ( $\mathrm{n}=19$ ).

The abundance of $M$. surinamicum showed significant differences with regard to the months $(H=21.21 ; \mathrm{p}<0.05)$ 
Table 1. Minimum, maximum, average and standard deviation values of salinity and water temperature at the six Macrobrachium surinamicum sampling sites in the Amazon estuary (Belém, Pará, Brazil), from May 2006 to April 2007.

\begin{tabular}{|c|c|c|c|c|c|c|c|c|}
\hline \multirow{2}{*}{ SITES } & \multicolumn{4}{|c|}{ SALINITY } & \multicolumn{4}{|c|}{ TEMPERATURE $\left({ }^{\circ} \mathrm{C}\right)$} \\
\hline & Min & Max & Average & SD & Min & Max & Average & SD \\
\hline Porto do Pelé & 0 & 5 & 2.1 & 2.43 & 25.25 & 27.25 & 26.54 & 0.81 \\
\hline Furo das Marinhas & 0 & 8 & 3.16 & 3.37 & 26 & 29 & 27.06 & 0.68 \\
\hline Arapiranga & 0 & 5 & 1.55 & 2.15 & 25 & 28 & 26.39 & 0.76 \\
\hline Icoaraci & 0 & 6 & 1.56 & 2.63 & 27 & 28.5 & 27.84 & 0.44 \\
\hline Belém & 0 & 5 & 1.45 & 2.27 & 24.5 & 29 & 26.41 & 0.75 \\
\hline Combu & 0 & 5 & 1.48 & 2.29 & 23.5 & 28 & 26.98 & 0.52 \\
\hline
\end{tabular}

Min = minimum; Max = maximum; $\mathrm{SD}=$ standard deviation.

$\mathrm{H}(5 ; 63)=25.39 ; \mathrm{p}<0.05$

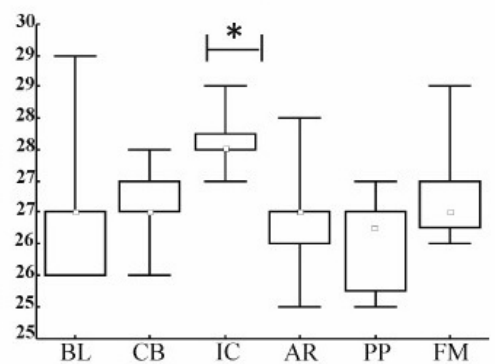

$H(11 ; 63)=10.27 ; p=0.51$
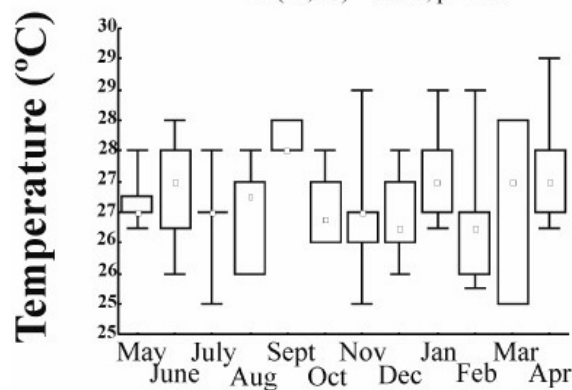

$H(1 ; 63)=0.18 ; p=0.66$

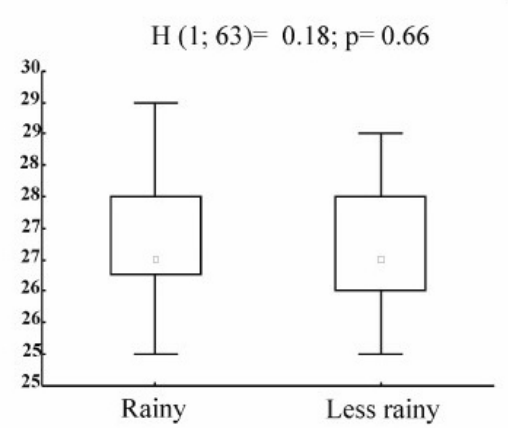

- Median

$25 \%-75 \%$

Min - Max

Sites
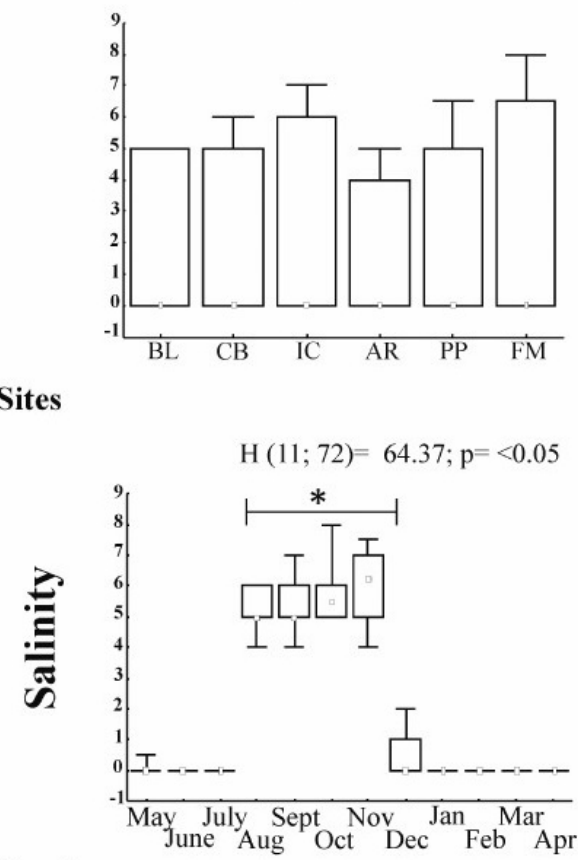

\section{Months}

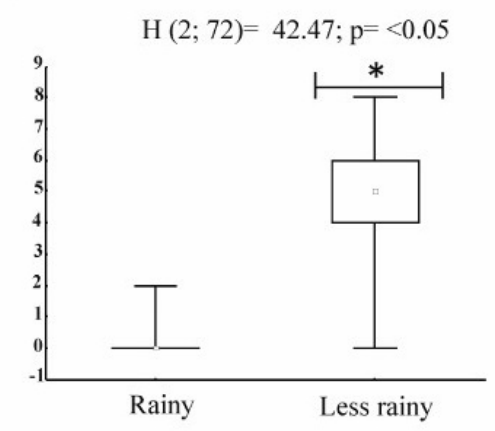

Seasons

Figure 3. Variation of abiotic factors (temperature and salinity) with respect to the sites, months and seasonal periods recorded in the Amazon estuary (Belém, Pará, Brazil) from May 2006 to April 2007; * = significant difference with $\mathrm{p}<0.05$. 
and it was significantly higher in December 2006 (Figure 4). However, it did not differ when the months were grouped into seasonal periods $(\mathrm{H}=1.77 ; \mathrm{p}=0.18)$, nor did it differ with respect to the sites $(\mathrm{H}=10.39 ; \mathrm{p}=0.06)$.

The abundance of $M$. surinamicum was not significantly correlated with temperature $(R=-0.008 ; \mathrm{p}>0.05)$, nor with salinity $(\mathrm{R}=0.01 ; \mathrm{p}>0.05)$ (Figure 5).

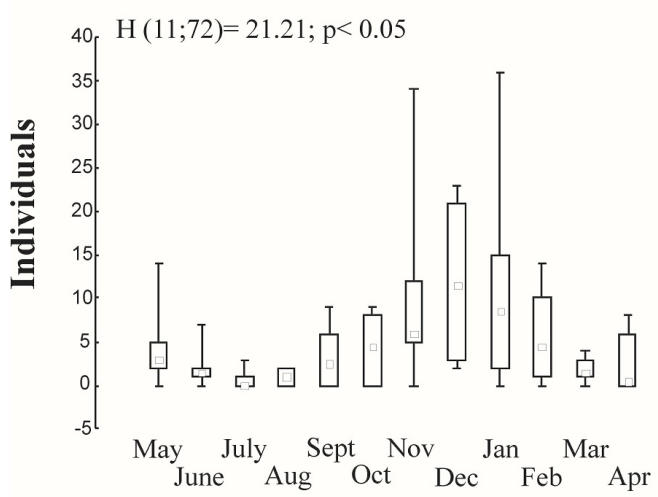

Months

\section{Discussion}

The occurrence and abundance of various species of decapod crustaceans are limited by environmental factors such as temperature and salinity, as in the case of M. potiuna (Müller, 1880), which was studied by Mattos and Oshiro (2009). These authors concluded that the predominance of immature shrimps during the months

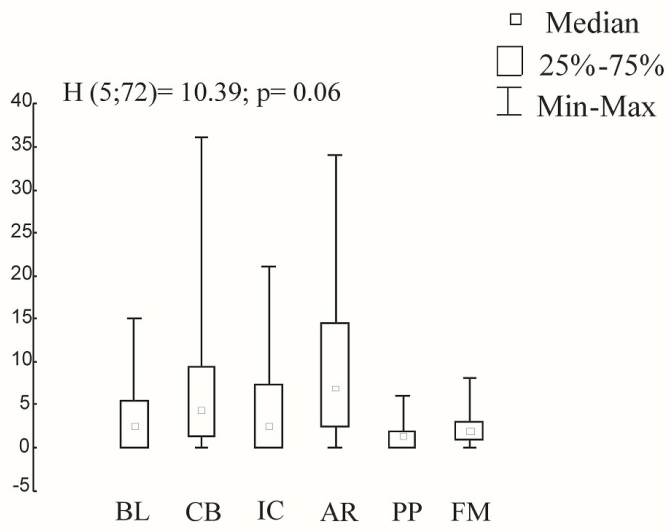

Sites

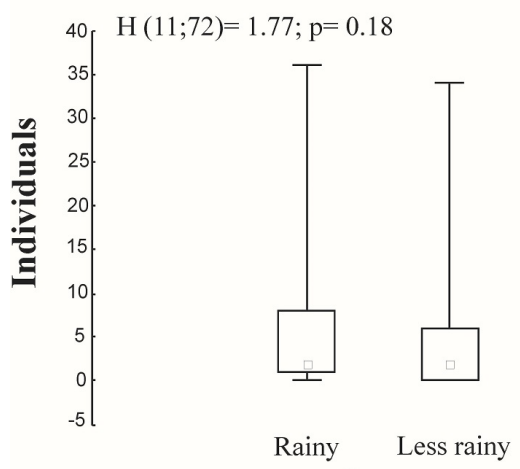

Seasons

Figure 4. Abundance of $M$. surinamicum with regard to the months, seasonal periods and sites of the Amazon estuary (Belém, Pará, Brazil) from May 2006 to April 2007.
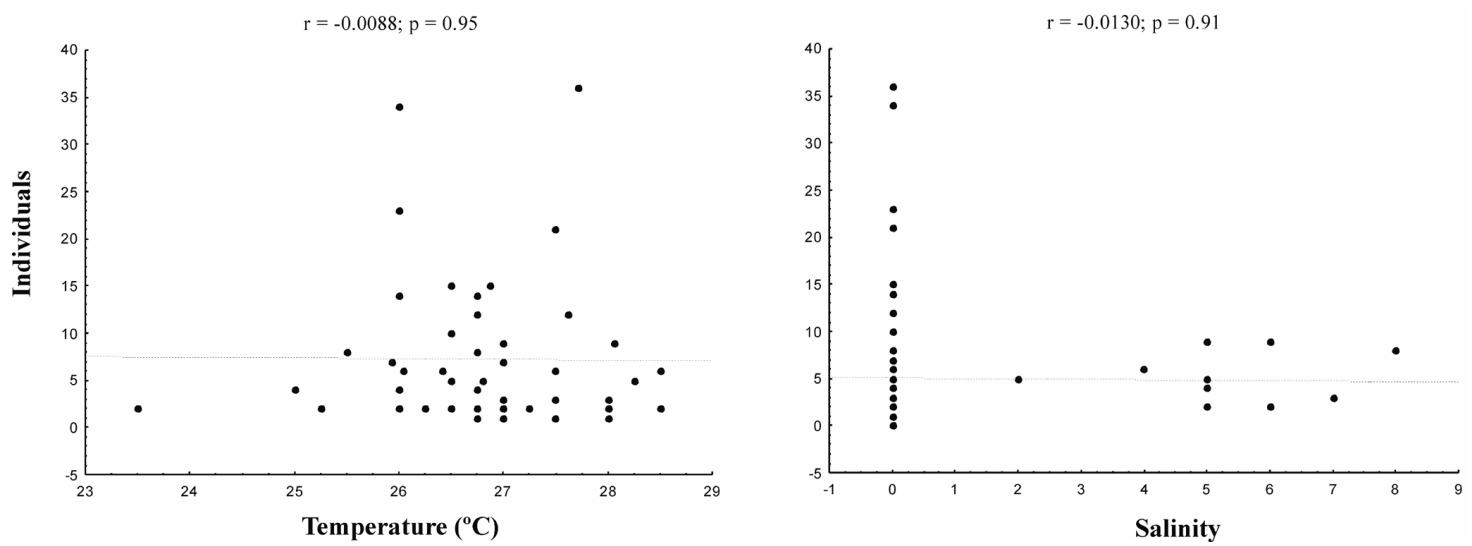

Figure 5. Correlation between abundance of M. surinamicum and abiotic factors (temperature and salinity) in Guajará Bay and surroundings, from May 2006 to April 2007. 
in which the water temperature did not exceed $21{ }^{\circ} \mathrm{C}$ indicated the close relationship between this abiotic factor and growth of individuals. Cavalcanti et al. (1986) found that $M$. rosenbergii (De Man, 1879) migrates to less depth areas in order to decrease the effects of temperatures lower than $15^{\circ} \mathrm{C}$.

Rainfall observed during the period studied in Guajará Bay is consistent with the definition of rainy (December to June) and dry (July to November) seasons described by Moraes et al. (2005). The year studied was apparently atypical, with values below and above the expected for June and November 2006, respectively.

Rainfall directly influences salinity, which is one of the most important environmental variables in any coastal aquatic habitat. It is relatively constant in high seas and varies considerably in intertidal zones, estuaries, lagoons and similar biotypes (Signoret and Brailovki, 2004). In the Guajará estuary, this factor ranged from zero to eight, where the highest value was recorded on Mosqueiro Island (Furo das Marinhas), which receives the greatest influence of marine water masses in periods of less rainfall. However, this factor did not influence significantly the abundance of M. surinamicum in this estuary. Mazzarelli et al. (2015) verified that zoeae I of $M$. amazonicum do not alter their metabolism due to the exposition to fresh or brackish water, but metabolism alterations were not followed by changes in free amino acids concentration in zoeae II and V exposed to fresh and brackish water.

Temperature variations $\left(23.5\right.$ to $\left.29.0^{\circ} \mathrm{C}\right)$ did not differ significantly throughout the study. They approached the temperature values found by Silva et al. (2002) in Vigia, State of Pará, from 1999 to 2001, where temperature ranged from 26 to $27.5^{\circ} \mathrm{C}$ during the rainy season and from 26 to $28^{\circ} \mathrm{C}$ in the less rainy season.

Temperature and salinity does not explain the fluctuation in abundance of M. surinamicum in Guajará Bay and Mosqueiro Island. The same fact was reported by Sampaio et al. (2007), who founded no correlation of physicochemical factors (temperature, dissolved oxygen, $\mathrm{pH}$ and salinity) with the catches of females of M. amazonicum of the Rio Jaguaribe, Itaiçaba, Ceará. Mantelatto and Barbosa (2005) and Pereira and Chacur (2009) also did not find any correlation between temperature and abundance of Macrobrachium brasiliense (Heller, 1862). And temperature and dissolved oxygen did not correlate significantly with the maturity of Macrobrachium olfersii prawns from Santa Maria da Vitória river, in Santa Leopoldina, ES, southeastern Brazil (Dornellas et al., 2011).

Although the abiotic factors studied have not explained the variation in abundance of $M$. surinamicum, it was evident that the abundance of this shrimp was significantly higher during the rainy season, contradicting Bentes et al. (2011) and Nóbrega et al. (2013), which recorded the largest catches of M. amazonicum during the less rainy season and during the transition to the dry season (less rainy). Higher abundances of $M$. surinamicum in rainiest months were also reported to the mouth of the Amazon River (Lima et al., 2015).
The seasonal variation of M. amazonicum had already been cited by Odinetz-Collart (1993). This author observed that largest catches in the floodplain lakes of the Amazon basin occur during droughts and floods and the lowest during high tides. This fact is due to a great spatial dispersion of individuals as a result of the increased volume of water. Still, this author states that the largest catches on the banks of the Amazon River are observed during the droughts (less rainy season), when shrimps migrate leaving behind the floodplain lakes, and the lowest catches are observed during the flood, due to the very high speed of water stream, which influences the catchability of the species. However, the maximum catch of M. surinamicum during the rainy season can be explained by the expansion of wet or flooded areas, when the species become more active and intensify their feeding and reproduction (Hartnoll, 1988).

Bentes et al. (2011) studied M. amazonicum in the same location and year in which our work was developed and found greater abundance in Icoaraci. The greater abundance of M. surinamicum registered on Arapiranga Island can be explained by the proximity of the island to the Icoaraci district, where the amount of suspended matter recorded is relatively high. This is an area of intense fish landing activity and there is also sewage disposal from food industries, contributing to an 'enrichment' of this site in terms of organic source material, which might be providing the increase in population.

This transport of organic matter can happen due to semidiurnal tidal action. However, it can be argued that Icoaraci is an area of intense human activity and that it can possibly result in a high degree of local contamination. This fact cannot be referenced as an advantage, but as justification for studying the long-term effects of the changes in biotic communities in this location and adjacent areas. Rodríguez-Almaraz et al. (2014) studied the condition and macrocrustaceans distribution of the Cumbres National Park of Monterrey in Mexico and concluded that M. acanthurus is outside of their geographical / ecological area and highlights the importance of studies to assess natural causes and anthropogenic factors that allowed the establishment of populations of this species to more distant areas.

Water contamination in Icoaraci suggests that there is a probable early eutrophication process, i.e., a gradual increase of the amount of nutrients (especially chemical compounds rich in phosphorus and nitrogen) due to the amount of domestic and industrial effluents in the area (not published data). This phenomenon would contribute to the excessive proliferation of microorganisms and the consequent deterioration of water quality, making it poor in oxygen.

Montoya (2003) studied the species M. amazonicum, M. surinamicum and M. jelskii in the delta of the Orinoco River (Venezuela) associated with water-hyacinths (floating aquatic vegetation Eichhornia crassipes (Martius) Solms) and found that where the amount of dissolved oxygen was lower, the greater was the participation of M. amazonicum and M. surinamicum in the local fauna composition. Similarly, Malassen and Valenti (2006) studied the effects 
of amount of nitrite in larval development of $M$. rosenbergii and concluded that probably, under high concentrations of this chemical compound, the species uses energy to adjust its physiological mechanisms against the toxic effects of nitrite, even reducing weight gain or decreasing the number of metamorphoses. Eventually, this strategy might be common to Macrobrachium species; however, this statement needs to be investigated.

Kawamura et al. (2015) observed post-larvae and juveniles in the early stages of $M$. rosenbergii in experiments by varying the $\mathrm{pH}$ of the water, they concluded that the survival, growth, size, shell quality and the distribution of $M$. rosenbergii larvae were adversely affected by low $\mathrm{pH}$ (4 and 5). The authors state that in natural environments, changes in $\mathrm{pH}$ by acid rain can decimate populations of this shrimp and be a major threat to aquatic ecosystems.

The tolerance of freshwater shrimps to different concentrations of pollutants should be investigated with a view to industrial growth surrounding Guajará Bay. Apparently, populations of $M$. surinamicum tolerate a relatively wide spectrum of concentrations of different contaminating elements; however, this needs to be further studied, since the greatest abundance of this shrimp was observed around the industrial pole and not at the closest location to it.

\section{Acknowledgements}

We are thankful to our colleagues Morgana Carvalho de Almeida, Roberto V. Espírito-Santo, Antônio Sérgio Carvalho, Priscila Amorim Carmona, Allan Jameson Silva de Jesus, Charles Michel Oliveira, Gilberto Meireles, Robson Silva, Franklin Jr., Marcelo, Leocyvan Nunes, Renata, Beatriz and Emílio Bentes; to fishermen João Rosa ('Parau'), Marinaldo (Naldo), Graça (Sister Graça) and Allan, for their support during sample collection, transport and selection of the biological material; to the National Council for Scientific and Technological Development (CNPq), Process No. 553125/2005-2, for funding the research and granting a doctoral fellowship to the second author. We are also thankful to the Support Program for Qualified Publications, Public Notice PAPQ, PROPESP/FADESP, of the Federal University of Pará, for funding the English version of the manuscript performed by Eduardo Gentile. All experiments were conducted under environmental permit (IBAMA/MMA No. 02018.00729/06-36).

\section{References}

AYRES, M., AYRES JUNIOR, M., AYRES, D.L. and SANTOS, A.S., 2007. BioEstat: aplicações estatísticas nas áreas das Ciências Biomédicas. Versão 5.0. Belém: Sociedade Civil Mamirauá. 364 p.

BENTES, B.S., MARTINELLI, J.M., SILVA, L.S., CAVALCANTE, D.V., ALMEIDA, M.C. and ISAAC, V.J., 2011. Spatial distribution of the amazon river prawn Macrobrachium amazonicum (Heller, 1862) (Decapoda, Caridea, Palaemonidae) in two perennial creeks of an estuary on the northern coast of Brazil (Guajará Bay, Belém, Pará). Brazilian Journal of Biology $=$ Revista Brasileira de
Biologia, vol. 71, no. 4, pp. 925-935. http://dx.doi.org/10.1590/ S1519-69842011000500013.

CAVALCANTE, D.V., 2008. Biodiversidade dos crustáceos decápodos das Ilhas do entorno de Belém, Pará. Belém: Universidade Federal do Pará. 38 p. Monografia de Graduação.

CAVALCANTI, L.B., CORREA, E.S. and CORDEIRO, E.A., 1986. Camarão: manual de cultivo do Macrobrachium rosenbergii (pitu havaiano - gigante da Malásia). Recife: Aquaconsult. 143 p.

CERVIGÓN, F., CIPRIANI, R., FISHER, W., GARIBALDI, L., HENDRICKX, M., LEMUS, A.J., MÁRQUEZ, R., POUTIRES, J.M., ROBAINA, G. and RODRIGUEZ, B., 1992. Guia de campo das especies comerciales marinas y de aguas salobres de la costa septentrional de Sur America. Roma: FAO. 513 p.

COELHO, P.A. and RAMOS-PORTO, M.A., 1985. Camarões de água doce do Brasil: distribuição geográfica. Revista Brasileira de Zoologia, vol. 2, no. 6, pp. 405-410. http://dx.doi.org/10.1590/ S0101-81751984000200014.

DORNELlAS, E.J., SILVA, F.M., MOTTA, D.G., SIMÕES, C.B. and SÁ, F.S., 2011. Ocorrência de Macrobrachium olfersii (Crustacea, Decapoda, Palaemonidae) em um afluente do Rio Santa Maria da Vitória, em Santa Leopoldina, ES, sudeste do Brasil. Natureza on line, vol. 9, no. 1, pp. 19-26.

ESPÍRITO-SANTO, R.V., ISAAC, V.J., SILVA, L.M.A., MARTINELLI, J.M., HIGUCHI, H. and SAINT-PAUL, U., 2005. Peixes e camarões do litoral bragantino, Pará, Brasil. Belém: MADAM. 268 p.

HARTNOLL, R.G., 1988. Evolution, systematics and geografical distribution. In: W.W. BURGREEN and B.R. MACMAHON, eds. Biology of the land crabs. Cambridge: Cambridge University Press, pp. 6-54.

KAWAMURA, G., BAGARINAO, T., YONG, A.S.K., CHEN, C.Y., NOOR, S.N.M. and LIM, L.S., 2015. Low pH affects survival, growth, size distribution, and carapace quality of the postlarvae and early juveniles of the freshwater prawn Macrobrachium rosenbergii de man. Ocean Science Journal, vol. 50, no. 2, pp. 371-379. http://dx.doi.org/10.1007/s12601-015-0034-0.

LIMA, J.F., DA CRUZ, M.C.M. and SILVA, L.M.A., 2015. Reproductive biology of Macrobrachium surinamicum (Decapoda: Palaemonidae) in the Amazon River mouth. Acta Amazonica, vol. 45, no. 2, pp. 299-306. http://dx.doi.org/10.1590/18094392201402824

MALASSEN, M. and VALENTI, W.C., 2006. Effect of nitrite on larval development of giant river prawn Macrobrachium rosenbergii. Aquaculture, vol. 261, no. 4, pp. 1292-1298. http:// dx.doi.org/10.1016/j.aquaculture.2006.07.048.

MANTELATTO, F L.M. and BARBOSA, L.R., 2005. Population structure and relative growth of freshwater prawn Macrobrachium brasiliense (Decapoda, Palaemonidae) from São Paulo State, Brazil. Acta Limnologica Brasiliensia, vol. 17, no. 3, pp. 245-255.

MATTOS, L.A. and OSHIRO, L.M.Y., 2009. Estrutura populacional de Macrobrachium potiuna (Crustacea, Palaemonidae) no Rio do Moinho, Mangaratiba, Rio de Janeiro, Brasil. Biota Neotropica, vol. 9, no. 1, pp. 81-86. http://dx.doi.org/10.1590/ S1676-06032009000100010.

MAZZARELLI, C.C.M., SANTOS, M.R., AMORIM, R.V. and AUGUSTO, A., 2015. Effect of salinity on the metabolism and osmoregulation of selected ontogenetic stages of an amazon population of Macrobrachium amazonicum shrimp (Decapoda, Palaemonidae). Brazilian Journal of Biology $=$ Revista 
Brasileira de Biologia, vol. 75, no. 2, pp. 372-379. http://dx.doi. org/10.1590/1519-6984.14413. PMid:26132021.

MELO, G.A.S., 2003. Manual de identificação dos Crustacea Decapoda de água doce do Brasil. São Paulo: Edições Loyola. 430 p.

MONTOYA, J.V., 2003. Freshwater Shrimps of the Genus Macrobrachium associated with Roots of Eichhornia crassipes (Water Hyacinth) in the Oricono Delta (Venezuela). Caribbean Journal of Science, vol. 39, no. 1, pp. 155-159.

MORAES, B.C., COSTA, J.M.N., COSTA, A.C.L. and COSTA, M.H., 2005. Variação espacial e temporal da precipitação no estado do Pará. Acta Amazonica, vol. 35, no. 2, pp. 207-214. http://dx.doi.org/10.1590/S0044-59672005000200010.

MOREIRA, E., 1966. Belém e sua expressão geográfica. Belém: Imprensa Universitária. 212 p.

NÓBREGA, P.S.V., BENTES, B. and MARTINELLI-LEMOS, J.M., 2013. Composition of shrimp populations (Crustacea: Decapoda) in non-vegetated areas of two river islands in a Brazilian Amazon estuary. Zoologia: an International Journal of Zoology, vol. 30, no. 6, pp. 652-660. http://dx.doi.org/10.1590/ S1984-46702013005000004.

ODINETZ-COLLART, O. and MOREIRA, L.C., 1993. Potencial pesqueiro de Macrobrachium amazonicum, na Amazônia Central (Ilha do Carneiro) variação da abundância e do comprimento. Amazoniana, vol. 3, pp. 399-413.

ODINETZ-COLLART, O., 1993. Ecologia e potencial pesqueiro do camarão canela Macrobrachium amazonicum, na Bacia Amazônica. Bases Científicas para Estratégias de Preservação e Desenvolvimento da Amazônia, vol. 2, pp. 147-166.

PEREIRA, M G.C. and CHACUR, M.M., 2009. Estrutura populacional de Macrobrachium brasiliense (Crustacea, Palaemonidae) do Córrego Escondido, Batayporã, Mato Grosso do Sul, Brasil. Rev. Biol. Neotrop., vol. 6, pp. 75-82.

PILEGGI, L.G., MAGALHÃES, C., BOND-BUCKUP, G. and MANTELATTO, F.L., 2013. New records and extension of the known distribution of some freshwater shrimps in Brazil. Revista Mexicana de Biodiversidad, vol. 84, no. 2, pp. 563-574. http:// dx.doi.org/10.7550/rmb.30504.
RAMOS, J., 2004. Poluição e contaminação da orla de Belém/ PA. In: S. UHLY and E.L. SOUZA. A questão da água na grande Belém. Belém: Casa de Estudos Germânicos da UFPA, pp. 121-148.

RIBEIRO, K.T.S., 2004. Água e saúde humana em Belém. Belém: Cejup. 280 p

RODRÍGUEZ-ALMARAZ, G.A., ORTEGA-VIDALES, V. and TREVIÑO-FLORES, J.A., 2014. Macrocrustáceos del Parque Nacional Cumbres de Monterrey, México: distribución y estado de conservación. Rev. Mex. Biodiv., vol. 85, no. 1, pp. 276-293. http://dx.doi.org/10.7550/rmb.34967.

SAMPAIO, C.M.S., SILVA, R.R., SANTOS, J.A. and SALES, S.P., 2007. Reproductive cycle of Macrobrachium amazonicum females (Crustacea, Palaemonidae). Brazilian Journal of Biology = Revista Brasileira de Biologia, vol. 67, no. 3, pp. 551-559. http:// dx.doi.org/10.1590/S1519-69842007000300022. PMid:18094840.

SHORT, J.W., 2004. A revision of Australian river prawns, Macrobrachium (Crustacea: Decapoda: Palaemonidae). Hydrobiologia, vol. 525, no. 1-3, pp. 1-100. http://dx.doi. org/10.1023/B:HYDR.0000038871.50730.95.

SIGNORET, G.P.B. and BRAILOVKI, D.S., 2004. Adaptive osmotic responses of Macrobrachium acanthurus (Wiegmann) and Macrobrachium carcinus (Linnaeus) (Decapoda, Palaemonidae) from the Southern Gulf of Mexico. Crustaceana, vol. 77, no. 4, pp. $455-465$.

SILVA, K.C., SOUZA, R A.L. and CINTRA, I.H.A., 2002. Camarão-cascudo Macrobrachium amazonicum (Heller, 1862) (Crustacea, Decapoda, Palaemonidae) no município de Vigia Pará - Brasil. Boletim Técnico Cientifico do CEPNOR, vol. 1, no. 2, pp. 41-73.

SILVA, R.R., SAMPAIO, C.M. and SANTOS, J.A., 2004. Fecundity and fertility of Macrobrachium amazonicum. Brazilian Journal of Biology = Revista Brasileira de Biologia, vol. 64, no. 3A, pp. 489-500. http://dx.doi.org/10.1590/S1519-69842004000300012. PMid:15622846.

STATSOFT, 2004. [viewed 10 April 2007]. Statistica: data analysis software system. Version 7 [online]. Cary. Available from: www.statsoft.com

VALENTI, W.C., 1996. Criação de camarões em águas interiores. Jaboticabal: Funep. 81 p. Boletim Técnico CAUNESP, vol. 2. 